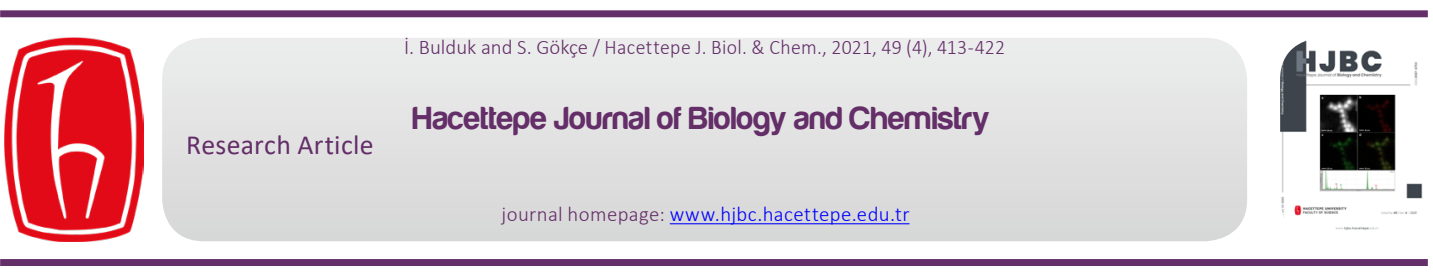

\title{
Development and Validation of a Effective and Reliable HPLC Method for the Quantification of Levodopa and Carbidopa in Pharmaceutical Formulations
}

\section{Farmasötik Formülasyonlarda Levodopa ve Karbidopa Miktarının Belirlenmesi için Etkili ve Güvenilir bir HPLC Yönteminin Geliştirilmesi ve Validasyonu}

\author{
ibrahim Bulduk ${ }^{1 \oplus}$, süleyman Gökçe ${ }^{2 \oplus}$ \\ ${ }^{1}$ Health High School, Usak University, Usak, Turkey. \\ ${ }^{2}$ Central Research Center, Usak University, Usak, Turkey.
}

\section{ABSTRACT}

convenient and simple high performance liquid chromatography method for simultaneous separation, determination and identification of levodopa and carbidopa in pharmaceutical formulation has been developed. The analysis was carried out using Ace $\mathrm{C} 18(4.6 \times 250 \mathrm{~mm}, 5 \mu \mathrm{m})$ column, and the separation was performed using a mobile phase consisting of 50 $\mathrm{mM} \mathrm{KH} 2 \mathrm{PO} 4\left(\mathrm{pH}\right.$ 2.3) pumped at a flow rate of $1.2 \mathrm{~mL} \mathrm{~min}^{-1}$ with UV detection at $280 \mathrm{~nm}$. The method has been successfully validated on the basis of the International Conference on Harmonization (ICH) acceptance criteria. The method is selective, since no interferences corresponding to these analytes were found at retention times. Retention times for both drugs were $2.939 \mathrm{~min}$ and 5.018 for levodopa and carbidopa, respectively. The method was validated and shown to be linear in the concentration range of 25-125 $\mathrm{g} \mathrm{mL}^{-1}$ and $6.25-31.25 \mathrm{\mu g} \mathrm{mL}^{-1}$ for levodopa and carbidopa, respectively. The method exhibited good linearity (R2 > 0.999) over the assayed concentration range and showed good intra-day and inter-day precision. The limit of detection (LOD) and limit of quantification (LOQ) were determined based on standard deviation of the intercept and the slope of the calibration curve. LOD and LOQ values were $0.70 \mu \mathrm{g} \mathrm{m}^{-1}$ and $2.13 \mu \mathrm{g} \mathrm{mL}^{-1}$ for levodopa and $1.31 \mu \mathrm{gL}^{-1}$ and $3.96 \mu \mathrm{g} \mathrm{mL}^{-1}$ for carbidopa, respectively. The method's accuracy was tested by adding known volume of standard solution (75 percent, 100 percent, and 125 percent concentration of the sample) to the 100 percent concentration pre-analyzed sample solution. The percentage mean recovery by standard addition experiments of levodopa and carbidopa is $99.75 \%$ and $99.55 \%$, respectively. This method has also been successfully used for the determination of levodopa and carbidopa in pharmaceutical formulations.

Key Words

Levodopa, carbidopa, validation, HPLC-UV.

\section{öz}

\begin{abstract}
- armasötik formülasyonlarda levodopa ve karbidopanın eşzamanlı olarak ayrılması, tanımlanması ve belirlenmesi için - uygun ve basit yüksek performanslı sıvı kromatografi yöntemi geliştirilmiştir. Analiz, Ace C18 (5 m, 4.6 x $250 \mathrm{~mm})$ kolonu kullanılarak gerçekleştirildi ve ayırma, UV ile $1.2 \mathrm{~mL} \mathrm{~min}^{-1}$ akıs hızında pompalanan $50 \mathrm{mM} \mathrm{KH}_{2} \mathrm{PO}_{4}(\mathrm{pH}$ 2.3) içeren bir mobil faz kullanılarak ve $280 \mathrm{~nm}$ 'de dedekte edilerek gerçekleştirildi. Yöntem, Uluslararası Uyum Konferansı (ICH) kabul kriterleri temelinde valide edilmiştir. Alıkonma zamanlarında bu analitlere karşılık gelen hiçbir girişim bulunmadığından metod seçicidir. Her iki ilaç için alıkonma süreleri levodopa ve karbidopa için sırasıyla 2.939 dakika ve 5.018 idi. Analiz metodu valide edilmiş ve levodopa ve karbidopa için sırasıyla 25-125 $\mathrm{g} \mathrm{mL}^{-1}$ ve 6.25-31.25 $\mathrm{g} \mathrm{mL}^{-1}$ konsantrasyon aralığında doğrusal olduğu gösterilmiştir. Analiz metodu, analiz edilen konsantrasyon aralığında iyi doğrusalıık $\left(R^{2}>0.999\right)$ sergiledi ve gün içi ve günler arası iyi kesinlik gösterdi. Teşhis limiti (LOD) ve tayin limiti (LOQ), kalibrasyon eğrisinin eğiminin ve kaymasının standart sapmasına göre belirlenmiştir. LOD ve LOQ değerleri levodopa için sırasıyla $0.70 \mu \mathrm{g} \mathrm{mL}^{-1}$ ve $2.13 \mu \mathrm{g} \mathrm{mL}{ }^{-1}$ ve karbidopa için $1.31 \mu \mathrm{g} \mathrm{mL} L^{-1}$ ve $3.96 \mu \mathrm{g} \mathrm{mL}^{-1}$ idi. Yöntemin doğruluğu, önceden analiz edilen yüzde 100 konsantrasyona bilinen bir hacimde standart çözelti (yüzde 75, yüzde 100 ve yüzde 125 konsantrasyon) ilave edilerek test edildi. Standart levodopa ve karbidopa ilavesiyle ortalama geri kazanım yüzdesi sırasıyla \%99.75 ve \%99.55'tir. Bu metod, farmasötik formülasyonlarda levodopa ve karbidopa tayini için de başarılı bir şekilde kullanılmıştır.
\end{abstract}

\section{Anahtar Kelimeler}

Levodopa, karbidopa, validasyon, HPLC-UV. 


\section{INTRODUCTION}

Destat uring the last few years, New medicines have become available for treating Parkinson's disease. Nevertheless, Since the administration of dopamine supplementation, levodopa has been considered a gold standard treatment for motor symptoms [1-3]. Levodopa is a natural precursor of dopamine and is used as a prodrug, as levodopa may cross the brain-blood barrier, contrary to dopamine. The physicochemical properties of Levodopa are given in table 1 [4].

Levodopa is usually associated with enzymatic inhibitors such as carbidopa, benserazide, tolcapone or entacapone due to its extensive metabolization in extracerebral tissues [5]. The physicochemical properties of carbidopa are given in table 2 [6].

Long-term use of levodopa leads to motor problems and variations such as the "wearing-off " condition characterized by moments without the benefits of therapy and moments with its advantages but with additional dyskinesia. Research has shown that high levodopa doses have also been associated with patient dyskinesia [7]. It is therefore recommended that doses of levodopa be modified according to the patient's individual needs based on clinical response and adverse event profile [1]. Several analytical methods for the determination of levodopa and its metabolites in biological matrices have been identified in the literature using high-performance liquid chromatography and various detection techniques such as electrochemical detection [8-16], tandem mass spectrometry (MS-MS) [17-22], and fluorescence $[23,24]$. Most of the above methods have a common low sensitivity limitation and long chromatographic run time.

Therefore, the purpose of this study was to develop and validate a robust and efficient HPLC method to determine the amount of levodopa and carbidopa in drug formulations in a pharmaceutical laboratory for the routine quality control study. The pharmaceutical industries use the time-consuming LC method and various mobile phases for different dosage forms of drugs. But with the system being developed, the cost and time required to adjust mobile phases could be avoided, as only one mobile phase could be used for all drugs and their combinations. The method should be applied from drug release experiments with prototypes and marketed fixed-dose combinations and to determine the quantity of samples under compendial testing conditions. Hence the method needs to be robust against matrix effects caused by formulation excitements.

Table 1. Physicochemical properties of levodopa.

Structure of molecules

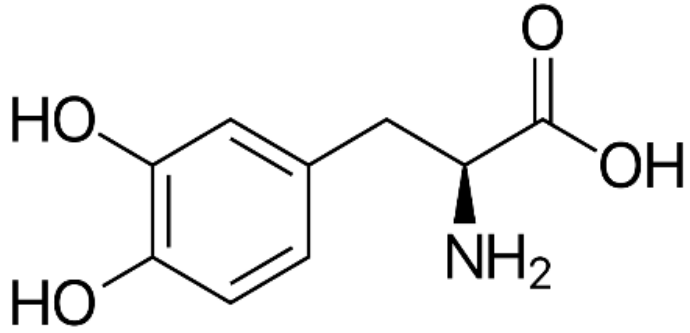


Table 2. Physicochemical properties of carbidopa.

Structure of molecules

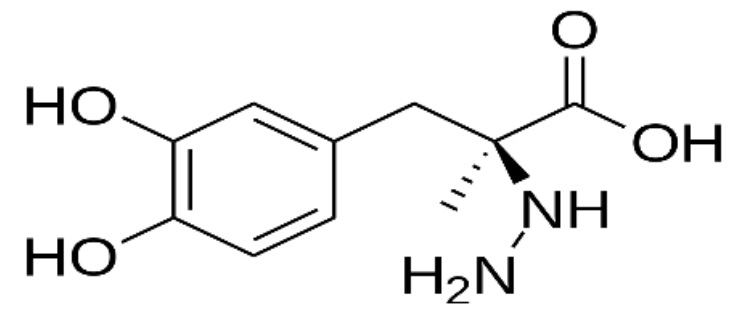

\section{MATERIALS and METHODS}

\section{Reagents}

All of the chemicals were used without further purification in this study. Levodopa and carbidopa standards were acquired from Sigma-Aldrich (Istanbul, Turkey). Pharmaceutical tablets were bought from local pharmacies. Potassium dihydrogen phosphate, orthophosphoric acid, and triethylamine have been purchased from Merck Ltd. Ultrapure water was obtained using a Milli-Q System with a conductivity lower than $0.05 \mu \mathrm{S} /$ $\mathrm{cm}$.

\section{Chromatographic Conditions.}

Chromatographic analysis was carried out on column Ace 5 C18 (5 $\mu \mathrm{m}, 250 \times 4.6 \mathrm{~mm})$. The mobile phase was $0.05 \mathrm{M}$ phosphate buffer $(\mathrm{pH} 2,3)$. For buffer solution: 6.80 g. potassium dihydrogen phosphate was accurately weighed. The volume was completed in liters by dissolving in deionized water. $5 \mathrm{~mL}$ of triethylamine was added. The $\mathrm{pH}$ of the obtained solution was adjusted to 2.3 by adding orthophosphoric acid. The mobile phase was filtered through a 0.22 micron membrane filter and degassed prior to use. Chromatographic analysis was carried out at a temperature of $30^{\circ} \mathrm{C}$ using a flow rate of $1.2 \mathrm{~mL} \mathrm{~min}^{-1}$ and a run time of $10 \mathrm{~min}$. The amount of injection was $20 \mu \mathrm{L}$, and the ultraviolet measurement was $280 \mathrm{~nm}$. The mobile phase has been used as a diluent and blank preparation.

\section{Standard Solution.}

The standards of $100 \mathrm{mg}$ levodopa and $25 \mathrm{mg}$ carbidopa were accurately weighed and transferred to a $100 \mathrm{~mL}$ volumetric flask, mixed with $50 \mathrm{~mL}$ of ultrapure water, dissolved in an ultrasonic bath, equilibrated to room temperature, completed with volume ultrapure water and mixed. This prepared solution was called as stock standard solution. Standard solutions were prepared by diluting from stock standard solution with ultrapure water so that the final levodopa concentration was 25 , 50, 75, 100 and $125 \mathrm{mg} \mathrm{mL}^{-1}$.

\section{Sample Preparation.}

Ten tablets were weighed and crushed in mortar and ground into a fine powder. Powder samples equal to 50 $\mathrm{mg}$ of levodopa and $12.5 \mathrm{mg}$ were placed in a $500 \mathrm{~mL}$ volumetric flask, diluted with $400 \mathrm{~mL}$ of deionized water and dissolved in an ultrasonic bath for 30 minutes. Equilibrated at room temperature. The volume was completed with $500 \mathrm{~mL}$ of deionized water. All samples were filtered through a $0.45 \mu \mathrm{m}$ membrane filter before injection. 


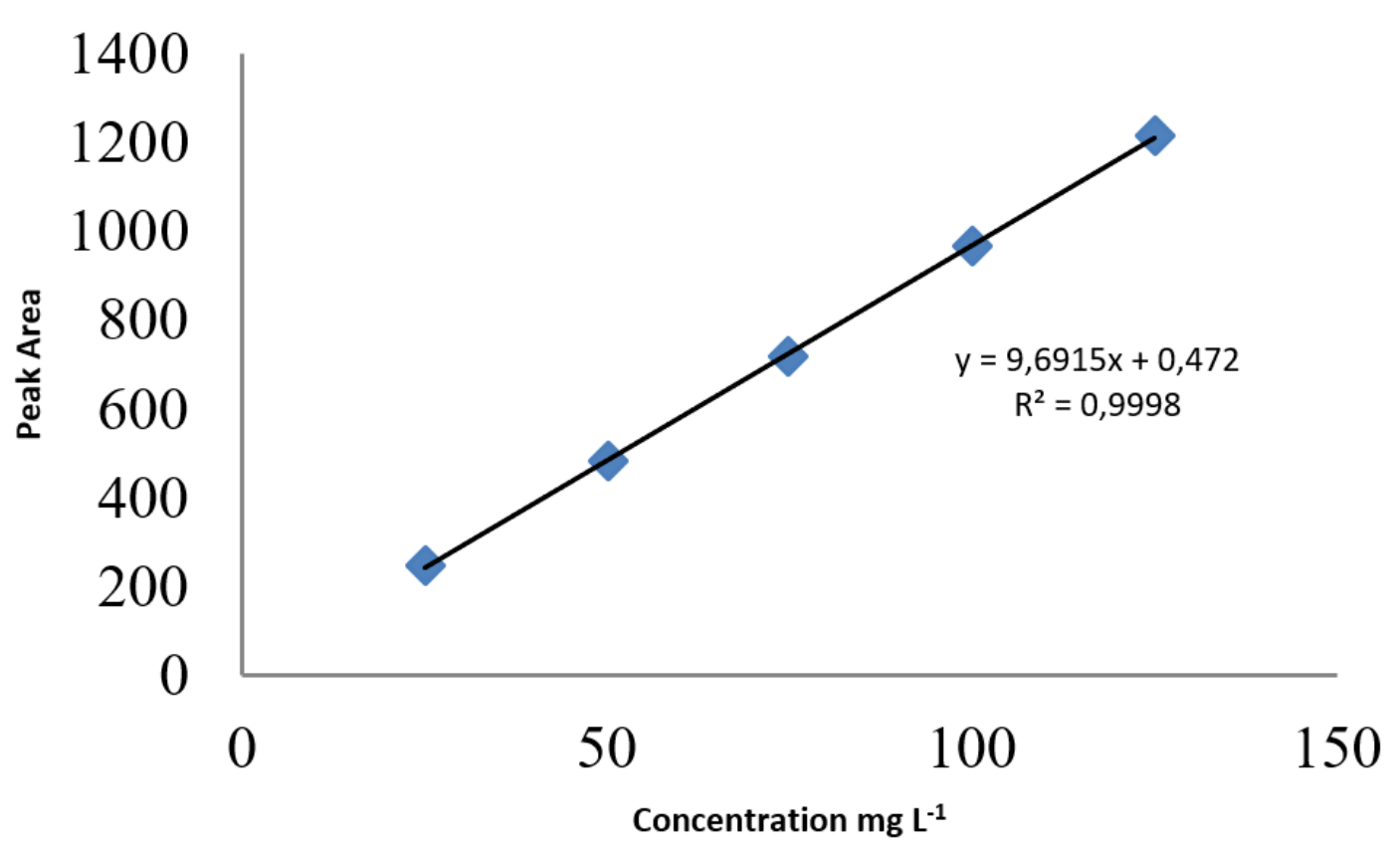

Figure 1. Calibration curve for levodopa standard solutions.

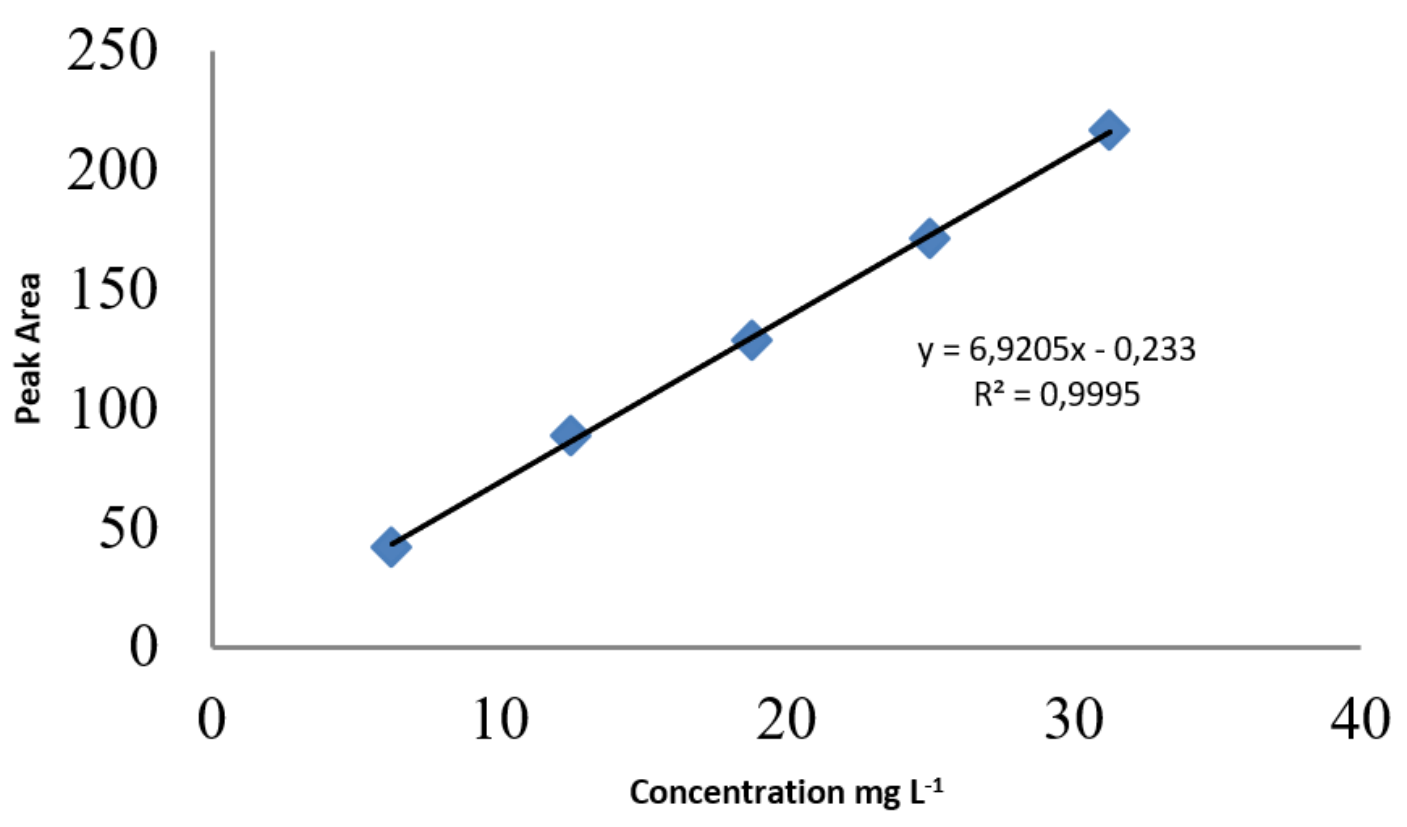

Figure 2. Calibration curve for carbidopa standard solutions. 
i. Bulduk and S. Gökçe / Hacettepe J. Biol. \& Chem., 2021, 49 (4), 413-422 417

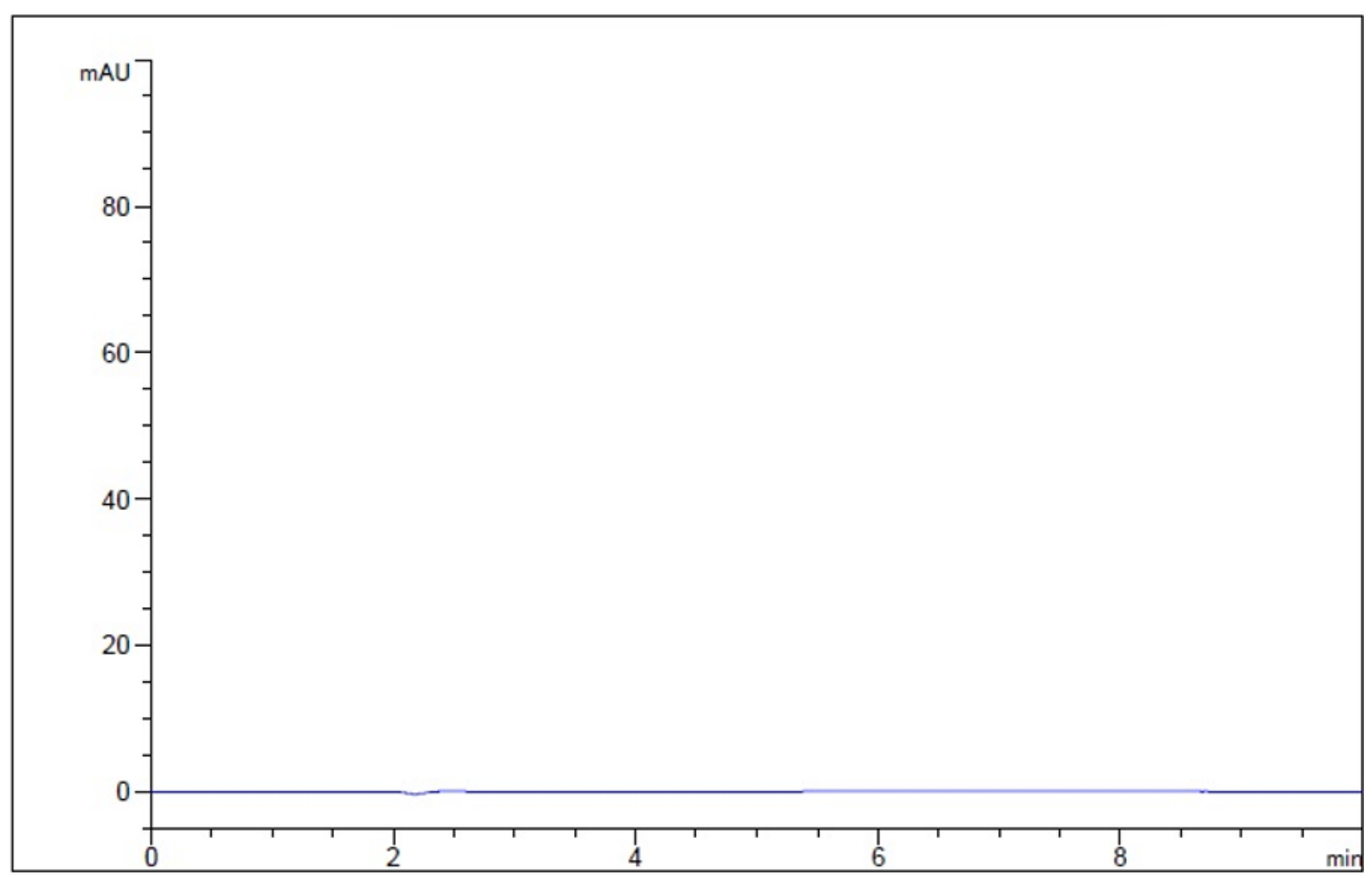

Figure 3. Blank chromatogram.

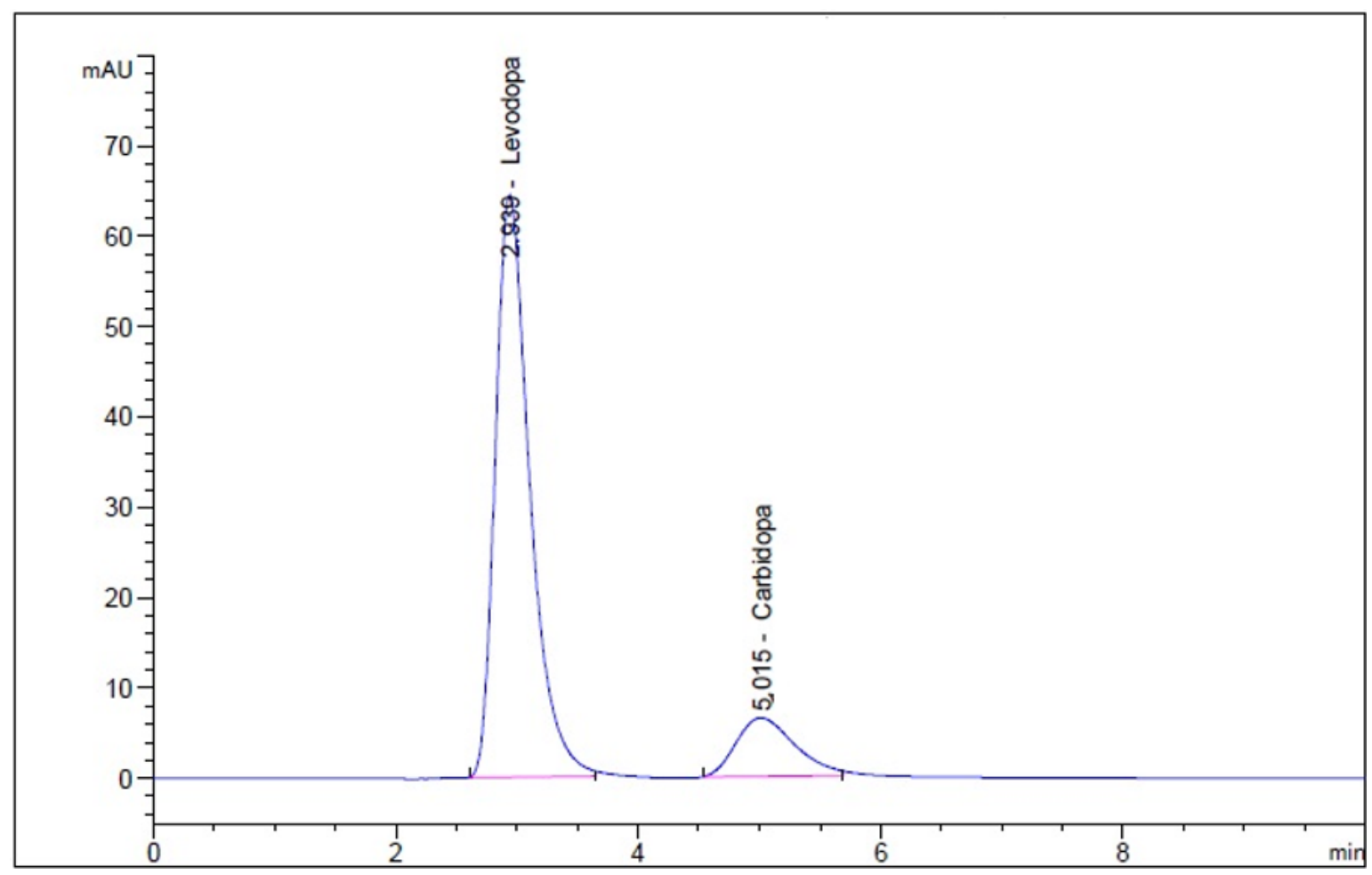

Figure 4. Chromatogram of levodopa and carbidopa standard solution. 


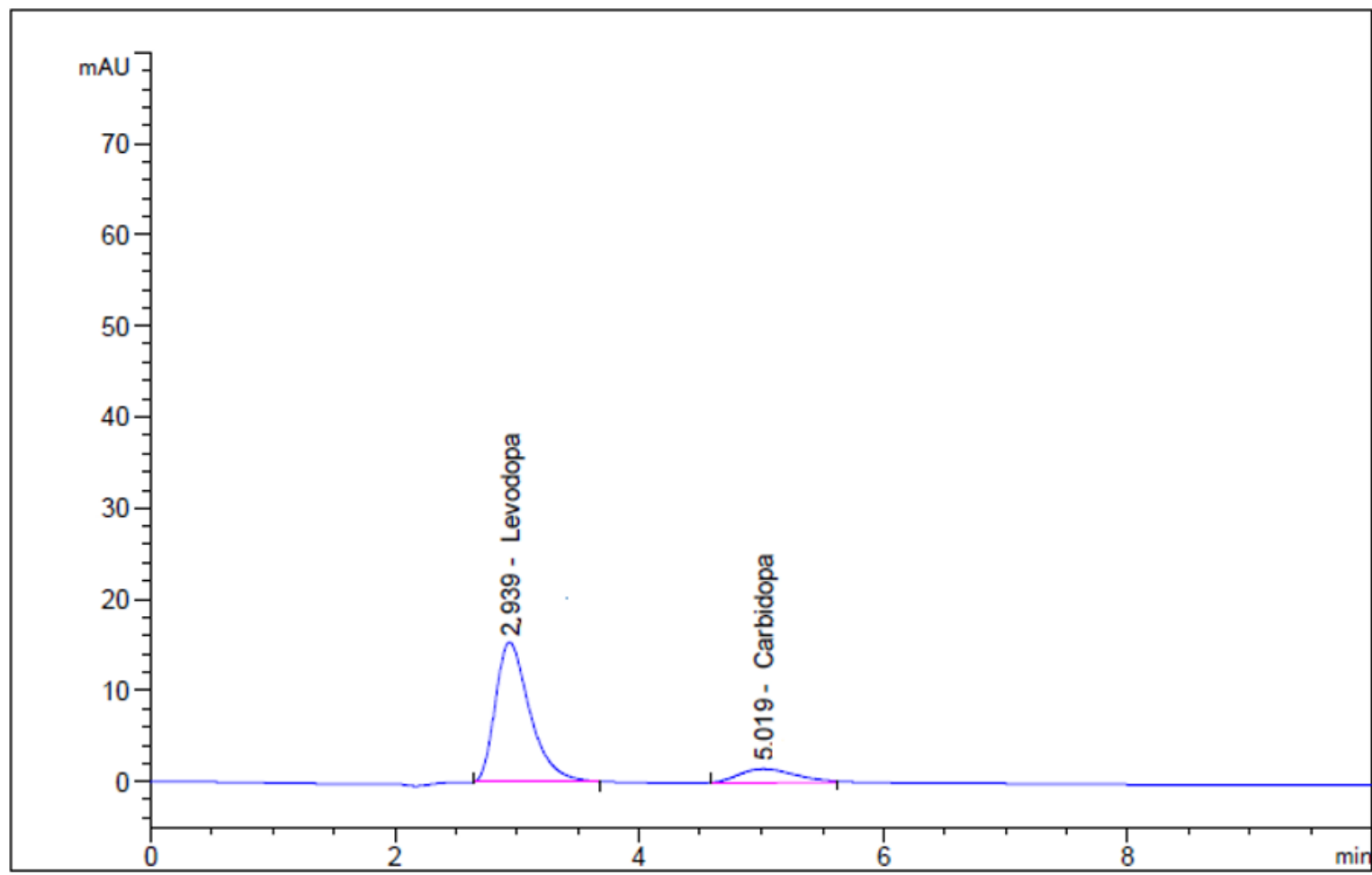

Figure 5. Chromatogram of pharmaceutical sample.

\section{Validation Procedure}

The validation of the new HPLC approach was performed in compliance with the recommendations for validation of the International Conference on Harmonization and the United States Pharmacopoeia [12, 13]. Parameters analyzed include linearity, accuracy, precision, the limit of detection (LOD), limit of determination (LOQ), specificity, the suitability of the system and robustness.

The new HPLC method was primarily designed for measuring high drug loads and the release of drugs. However, the method should also be applied in routine testing as much as possible, for instance for testing pharmaceutical formulations. For the second reason, the method must ensure that the drug is properly identified within a broad range of concentrations.

The UV detection was performed at $280 \mathrm{~nm}$. A specific concentration range was selected for the validation procedure based on those considerations. Accordingly, the concentration ranges for the method validation were 25-125 $\mathrm{mg} \mathrm{mL}^{-1}$ for levodopa and 6.25-31.25 $\mu \mathrm{g}$ $\mathrm{mL}^{-1}$ for carbidopa.

The linearity of the analytical method was determined by preparing and injecting standard solutions in the range of 25 to $125 \mathrm{mg} \mathrm{mL}^{-1}$ of levodopa and 6.25 to $31.25 \mathrm{mg} \mathrm{mL}^{-1}$ of carbidopa solution. The calibration curves were formed by drawing the peak areas against the concentrations of levodopa and carbidopa and the regression equation slope and intersection point were calculated. Each solution was injected triplicate. Averages of the peak areas have been used. Three separate series of calibration standards have been prepared for each calibration interval in order to create linearity.

Accuracy, expressed as mean absolute recovery and percent relative standard deviation (percent RSD), for each concentration of the specified ranges was assessed in triplicate

The precision of the novel method expressed as repeatability (intraday) and intermediate precision (interday) was measured by the preparation of six individual samples of the lowest, medium and highest concentration of levodopa and carbidopa working range. Interday precision standards were prepared in the same way and analyzed on three consecutive days. Repeatability and intermediate precision were assessed by absolute recovery and RSD percent of the calculated concentrations. 
Table 3. Results of HPLC method validation.

\begin{tabular}{|c|c|c|c|}
\hline \multicolumn{2}{|c|}{ Parameter } & \multicolumn{2}{|c|}{ Values } \\
\hline & & Levodopa & Carbidopa \\
\hline \multicolumn{2}{|c|}{ Retention time min. } & 2.940 & 5.018 \\
\hline \multicolumn{2}{|c|}{ Calibration range $\mu \mathrm{g} \mathrm{mL}^{-1}$} & $25-125$ & $6.25-31.25$ \\
\hline \multicolumn{2}{|c|}{ Correlation Coefficient $\left(\mathrm{R}^{2}\right)$} & 0.9999/0.9998/0.9999 & 0.9994/0.9996/0.9992 \\
\hline \multirow[t]{2}{*}{ Accuracy } & Mean absolute recovery & $98.82-100.75 \%$ & $98.55-100.55 \%$ \\
\hline & $\%$ RSD & $0.10-0.75 \%$ & $0.05-0.55 \%$ \\
\hline Resolution & & & 2,94 \\
\hline \multicolumn{4}{|l|}{ Precision } \\
\hline \multirow{3}{*}{ Absolute recovery } & $\begin{array}{l}\text { Levodopa: } 30 \mu \mathrm{g} \mathrm{mL}^{-1} \\
\text { Carbidopa: } 7.50 \mu \mathrm{gL}^{-1}\end{array}$ & $98.76-100.62 \%$ & $98.27-100.61 \%$ \\
\hline & $\begin{array}{l}\text { Levodopa: } 60 \mu \mathrm{g} \mathrm{mL}^{-1} \\
\text { Carbidopa: } 15 \mu \mathrm{g} \mathrm{mL}\end{array}$ & $99.26-100.48 \%$ & $99.56-100.48 \%$ \\
\hline & $\begin{array}{l}\text { Levodopa: } 120 \mu \mathrm{g} \mathrm{mL}^{-1} \\
\text { Carbidopa: } 30 \mu \mathrm{gL}^{-1}\end{array}$ & $99.17-100.23 \%$ & $99.84-100.21 \%$ \\
\hline \multirow{3}{*}{$\begin{array}{l}\text { Repeatability } \\
\text { (\% RSD) }\end{array}$} & $\begin{array}{l}\text { Levodopa: } 30 \mu \mathrm{g} \mathrm{mL^{-1 }} \\
\text { Carbidopa: } 7.50 \mu \mathrm{mL}^{-1}\end{array}$ & $0.48 \%$ & $0.57 \%$ \\
\hline & $\begin{array}{l}\text { Levodopa: } 60 \mu \mathrm{g} \mathrm{mL}^{-1} \\
\text { Carbidopa: } 15 \mu \mathrm{gL}^{-1}\end{array}$ & $0.34 \%$ & $0.42 \%$ \\
\hline & $\begin{array}{l}\text { Levodopa: } 120 \mu \mathrm{g} \mathrm{mL}^{-1} \\
\text { Carbidopa: } 30 \mu \mathrm{g} \mathrm{mL}^{-1}\end{array}$ & $0.23 \%$ & $0.24 \%$ \\
\hline \multirow{3}{*}{$\begin{array}{l}\text { Intermediate precision } \\
\qquad(\% \text { RSD })\end{array}$} & $\begin{array}{l}\text { Levodopa: } 30 \mu \mathrm{g} \mathrm{mL}^{-1} \\
\text { Carbidopa: } 7.50 \mu \mathrm{gL}^{-1}\end{array}$ & $\begin{array}{l}0.47 \% \\
0.58 \% \\
0.62 \%\end{array}$ & $\begin{array}{l}0.48 \% \\
0.62 \% \\
0.57 \%\end{array}$ \\
\hline & $\begin{array}{l}\text { Levodopa: } 60 \mu \mathrm{g} \mathrm{mL}^{-1} \\
\text { Carbidopa: } 15 \mu \mathrm{g} \mathrm{mL}\end{array}$ & $\begin{array}{l}0.38 \% \\
0.43 \% \\
0.36 \%\end{array}$ & $\begin{array}{l}0.35 \% \\
0.43 \% \\
0.53 \%\end{array}$ \\
\hline & $\begin{array}{l}\text { Levodopa: } 120 \mu \mathrm{g} \mathrm{mL}^{-1} \\
\text { Carbidopa: } 30 \mu \mathrm{gL} \mathrm{m}^{-1}\end{array}$ & $\begin{array}{l}0.32 \% \\
0.18 \% \\
0.21 \%\end{array}$ & $\begin{array}{l}0.22 \% \\
0.18 \% \\
0.21 \%\end{array}$ \\
\hline \multicolumn{2}{|l|}{ Detection limit } & $0.94 \mu \mathrm{g} \mathrm{mL}^{-1}$ & $2.11 \mu \mathrm{g} \mathrm{mL} \mathrm{L}^{-1}$ \\
\hline \multicolumn{2}{|l|}{ Quantification limit } & $1.63 \mu \mathrm{g} \mathrm{mL}^{-1}$ & $2.56 \mu \mathrm{g} \mathrm{mL}^{-1}$ \\
\hline \multirow{5}{*}{ System suitability } & Symmetry factor & 0.66 & 0.72 \\
\hline & Retention factor & 2.64 & 2.75 \\
\hline & Plates number & 2990 & 5062 \\
\hline & $\begin{array}{l}\text { Peak areas } \\
(\% \text { RSD) }\end{array}$ & $0.155 \%$ & $0.345 \%$ \\
\hline & $\begin{array}{l}\text { Retention times } \\
\quad(\% \text { RSD })\end{array}$ & $0.028 \%$ & $0.053 \%$ \\
\hline \multicolumn{4}{|c|}{ Robustness (abs. mean recovery) } \\
\hline \multirow{2}{*}{ Mobile phase flow rate } & a) $1.18 \mathrm{~mL} \mathrm{~min}-1$ & $100.34 \%$ (0.12\% RSD) & $100.12 \%(0.12 \% \mathrm{RSD})$ \\
\hline & b) $1.22 \mathrm{~mL} \mathrm{~min}{ }^{-1}$ & $99.88 \%(0.05 \%$ RSD) & $99.80 \%(0.05 \%$ RSD) \\
\hline \multirow{2}{*}{ Column temperature } & a) 25 OC & $99.76 \%$ (0.07\% RSD) & $99.76 \%$ (0.06\% RSD) \\
\hline & b) $35 \mathrm{OC}$ & $100.21 \%$ (0.18\% RSD) & $100.21 \%$ (0.09\% RSD) \\
\hline \multirow{2}{*}{ Buffer concentration } & a) $0.045 \mathrm{M}$ & $100.86 \%$ (0.93\% RSD) & $100.54 \%$ (0.74\% RSD) \\
\hline & b) $0.055 \mathrm{M}$ & $99.91 \%$ (0.64\% RSD) & $99.84 \%$ (0.54\% RSD) \\
\hline \multirow{2}{*}{$\mathrm{pH}$ value } & a) 1.95 & $100.12 \%$ (0.71\% RSD) & $100.12 \%$ (0.65\% RSD) \\
\hline & b) 2.05 & $99.75 \%$ (0.63\% RSD) & $99.54 \%$ (0.54\% RSD) \\
\hline
\end{tabular}


The detection limit (LOD) of the drug is a characteristic value for the method's precision in which the corresponding compound is only measurable, whereas the quantitation limit (LOQ) is the lowest concentration with acceptable linearity, accuracy, and certainty. LOD was determined on the basis of a 3:1 signal-to-noise ratio, while LOQ was determined on a 10:1 signal-to-noise ratio.

The specificity which is an essential part of the validation of the method has been assessed as follows: First, a collection of this analyte's standard stock solution (levodopa and carbidopa reference material dissolved in ultrapure water) was prepared. Different concentrations of standard solutions were prepared in ultrapure water from the stock standard solution. Then, the impact of excipients used in the manufacture of the selected marketed dosage forms on the proper assessment of levodopa and carbidopa peaks was screened. After sample analysis, the chromatograms obtained were tested for peak area and excipient interference at retention periods of levodopa and carbidopa.

The suitability of the system was assessed by determining the tailing factor, retention factor, the number of theoretical plates and the reproducibility of peak areas and retention times. Additionally, for this analyte, calibration curves were established and linearity checked. Various method parameters were tested to assess the reliability and robustness of the proposed HPLC method.

Several parameters were considered to be critical to the analysis. The self-imposed parameters limits set for these parameters have been inspired by other publications and our own experience. We studied parameters as follows:

The flow of the mobile phase $\left( \pm 0.02 \mathrm{~mL} \mathrm{~min}^{-1}\right)$,

Column temperature $\left( \pm 5^{\circ} \mathrm{C}\right)$,

Buffer concentration ( $\pm 0.005 \mathrm{M})$ and

$\mathrm{pH}$ value $( \pm 0.05)$ for mobile phase

It was investigated these parameters by injecting a series of dilutions with three individual standards for lowest, medium and highest concentrations of levodopa and carbidopa in triplicate. The robustness of the system has been measured by absolute average recovery, RSD (precision) and $\mathrm{R}^{2}$ of the calibration curves that resulted.

\section{RESULTS and DISCUSSION}

\section{Development of the method}

The goal of the novel method was to demonstrate reasonable chromatographic performance and to be universally applicable on standard HPLC devices. In the early stages of the current method development, chromatographic methods with isocratic elution were tested with the column Ace 5 C18 (5 $\mathrm{m}, 250 \times 4.6 \mathrm{~mm})$. Later, an end-capped LiChrospher 100 RP-18 (250 x $4.6 \mathrm{~mm}$, $5 \mu \mathrm{m})$ was used to achieve better selectivity. A precolumn had been installed to shield the column from possible contamination. All of the literature methods cited include using a column of $250 \mathrm{~mm}$. This contributes to long run times or the need for higher flow speeds and is therefore time-consuming and expensive.

Since the goal was to develop a reliable and effective method, promising literature methods were moved to a shorter column in the next stage of system creation and screened for their applicability in levodopa and carbidopa detection.

Nevertheless, the findings from these experiments clearly showed that the transition to a shorter column with the same or fixed period did not allow for a proper peak symmetry and number of plates.

After this initial set of screening methods, it was clear that an isocratic separation of the analyte would be possible within a reasonable period of time.

Consequently, A phosphate buffer ( $\mathrm{pH}$ of 2.30) was chosen as a mobile phase based on these criteria. Furthermore, the chosen eluents have been designed for solvent $\mathrm{pH}$ and ionic resistance. The mobile phase was $0.05 \mathrm{M}$ phosphate buffer ( $\mathrm{pH}$ 2,3). For buffer solution: $6.80 \mathrm{~g}$ potassium dihydrogen phosphate was accurately weighed. The volume was completed in liters by dissolving in deionized water. 5 $\mathrm{mL}$ of triethylamine was added. The $\mathrm{pH}$ of the obtained solution was adjusted to 2.3 by adding orthophosphoric acid.

Appropriate volume for injection and column temperature were selected and the initial isocratic program was also modified step by step. Chromatographic analysis was conducted at $30{ }^{\circ} \mathrm{C}$ with a flow rate of $1.2 \mathrm{~mL} \mathrm{~min}^{-1}$ and a run time of $10 \mathrm{~min}$. The injection amount was $20 \mu \mathrm{L}$, and ultraviolet measurements were at $280 \mathrm{~nm}$. The mobile phase was used as a blank and diluent preparation. 


\section{Linearity}

The linear relation between concentrations of analytes and peak areas is expressed by the determination correlation coefficient $\left(R^{2}\right)$. For calibration curve over concentration ranges, linearity for levodopa and carbidopa could be shown, since all $R^{2}$ values were above 0.999 . The calibration curve regression analysis was shown in table 3 and figure 1, 2.

\section{Accuracy and precision}

Table 3 showed the results for precision and accuracy. At all concentrations, a consistent and high absolute recovery and low RSD percentage within the acceptance limit of \pm 5 percent of 100 percent drug recovery was demonstrated for analysis. The percentage of RSD results for repeatability and intermediate precision was less than 0.62 percent and was therefore considered acceptable.

\section{Specificity}

The new method's specificity was evaluated by first analyzing blank solvents/media, and then samples containing a single combination of drugs or drugs. The process showed good separation of the compound in standard solutions by chromatography. (levodopa and carbidopa reference material dissolved in ultrapure water). No peak interference was observed between the analytes with blank media, buffer components or excipients of the marketed dosage formulations. Interference studies were shown by injection of blank, sample and standard solution. No drug excipient interactions were observed. There was no peak at the retention time of levodopa and carbidopa (figures 3 and 4). This indicates that the blank and drug excipients did not interfere. The retention times were $2.940 \mathrm{~min}$ for levodopa and $5.018 \mathrm{~min}$ for carbidopa. The chromatogram of the drug sample is presented in Figure 5.

\section{System suitability}

Primary parameters to evaluate system suitability such as symmetry factor, retention factor or the number of theoretical plates were determined for the lowest $\left(30 \mu \mathrm{g} \mathrm{mL}^{-1}\right)$, medium $\left(60 \mu \mathrm{g} \mathrm{mL}^{-1}\right)$ and highest $\left(120 \mu \mathrm{g} \mathrm{mL}^{-1}\right)$ concentrations for levodopa and were listed in table 3. levodopa and carbidopa had excellent peak symmetry. In addition, the peaks of the analytes showed consistently low variability in peak areas and retention times. In all cases, the calibration curve coefficient in this study was above 0.999, which indicates that the method was suitable for samples with simple or rather complex matrices.

\section{Robustness}

The robustness study data show that the linearity, absolute mean recovery, and precision of the developed method remain unaffected by small changes in critical method parameters. The corresponding results have been shown in table 3. Temperature variations, flow rate, ionic strength, and $\mathrm{pH}$ value did not affect this analyte's recovered amount. The absolute mean drug recovery for all substances was between $99 \%$ and $101 \%$ and the level of RSD was less than $1.00 \%$. The resulting calibration curves showed good linearity, i.e. the determination coefficients were in all cases greater than 0.999.

\section{Conclusions}

An RP-HPLC method for an effective analysis of levodopa and carbidopa was developed and validated. There was no significant difference in the statistical comparison of the assay results for levodopa and carbidopa in tablet dosage forms by the method. The method allows a fast and robust quantification without any interference caused by formulation excipients or ingredients. The findings of the tablet dose study according to the analytical method are reliable, reproducible, and are in good agreement with drug label claims. Therefore this method can be used successfully in tablet dosage forms for routine analysis of levodopa and carbidopa.

\section{References}

1. S. Fahn, D. Oakes, I. Shoulson, K.Kieburtz, A. Rudolph, A. Lang, CW. Olanow, C. Tanner, K. Marek, Levodopa and the progression of Parkinson's disease, The New England Journal of Medicine, 351 (2004) 2498-2508.

2. CE. Clarke, M. Guttman, Dopamine Agonist Monotherapy in Parkinson's Disease, Lancet, 360 (9347 (2002) 1767-1769.

3. M. Rezak, Current pharmacotherapeutic treatment options in Parkinson's disease, Disease- a-Month: DM., 53 (2007) 214-222.

4. https://www.drugbank.ca/drugs/DB01235 Drug created on June 13, (2005) 07:24/Updated on June 12, 2020 11:41

5. D. Goncalves, G. Alves, P. Soares-da-Silva, A. Falcão, Bioanalytical chromatographic methods for the determination of catechol-O-methyltransferase inhibitors in rodents and human samples: a review, Analytica Chimica Acta, 710 (2012) 17-32.

6. https://www.drugbank.ca/drugs/DB00190 Drug created on June 13, (2005) 07:24/Updated on September 03, 2020 19:01

7. FJ. David, MR. Rafferty, JA. Robichaud, J. Prodoehl, WM. Kohrt, DE. Vaillan-court, DM. Corcos, Progressive resistance exercise and Parkinson's disease: a review of potential mechanisms. Parkinson's Disease, (2011; 2012): 124527. 
8. J.M. Cedarbaum, R.Williamson, H. Kutt, Simultaneous determination of levodopa, its metabolites and carbidopa in clinical samples, Journal of Chromatography B: Biomedical Sciences and Applications, 415 (1987) 393-399.

9. Y. Michotte, M. Moors, D.Deleu, P. Herregodts, G. Ebinger, 3-O-methyldopa and dopamine in plasma using high performance liquid chromatography with electrochemical detection, Journal of Pharmaceutical and Biomedical Analysis, 5 (1987) 659-664.

10. DC. Titus, TF. August, KC. Yeh, R. Eisenhandler, WF. Bayne, DG. Musson, Simultaneous high-performance liquid chromatographic analysis of carbidopa, levodopa and 3-O-methyldopa in plasma and carbidopa, levodopa and dopamine in urine using electrochemical detection, Journal of Chromatography B: Biomedical Sciences and Applications, 534 (1990) 87-100.

11. KA. Sagar, MR. Smyth, Simultaneous determination of levodopa, carbidopa and their metabolites in human plasma and urine samples using LC-EC, J. Pharm. Biomed. Anal., 22 (2000) 613-624.

12. V. Rizzo, M. Memmi, R. Moratti, G. Melzi d’Eril, E. Perucca, Concentrations of L-dopa in plasma and plasma ultrafiltrates, Journal of Pharmaceutical and Biomedical Analysis, 14 (1996) 1043-1046.

13. T. Wikberg, Simultaneous determination of levodopa, its main metabolites and carbidopa in plasma by liquid chromatography, Journal of Pharmaceutical and Biomedical Analysis, 9 (1991); 167-176.

14. M. Karimi, JL. Carl, S.Loftin, JS. Perlmutter, Modified highperformance liquid chromatography with electrochemical detection method for plasma measurement of levodopa, 3-O-methyldopa, dopamine, carbidopa and 3,4-dihydroxyphenyl acetic acid, Journal of chromatography. $B$, Analytical Technologies in the Biomedical and Life Sciences, 836(1-2) (2006); 120-123.

15. F. Bugamelli, C. Marcheselli, E. Barba, MA. Raggi, Determination of L-dopa, carbidopa, 3-O-methyldopa and entacapone in human plasma by HPLC-ED, Journal of Pharmaceutical and Biomedical Analysis, 54(3) (2011) 562 567.

16. M. Kuoppamaki, K. Korpela, R. Marttila, V. Kaasinen, P. Hartikainen, J. Lyytinen, S. Kaakkola, J. Hanninen, E. Loyttyniemi, M. Kailajarvi, P. Ruokoniemi, J. Ellmen, Comparison of pharmacokinetic profile of levodopa throughout the day between levodopa/carbidopa/ entacapone and levodopa/carbidopa when administered four or five times daily, European Journal of Clinical Pharmacology, 65 (2009) 443-455.
17. C. César Ida, RM. Byrro, FF. Cardoso, IM. Mundim, S. Teixeira Lde, EP. da Silva, SA. Gomes, RR. Bonfim, GA. Pianetti, Simultaneous quantitation of levodopa and 3-Omethyldopa in human plasma by HPLC-ESI-MS/MS: Application for a pharmacokinetic study with a levodopa/benserazide formulation, Journal of Pharmaceutical and Biomedical Analysis, 56 (2011) 1094-1100.

18. HF. Martins, DP. Pinto, AV. Nascimento, MAS. Marques, FC. Amendoeira, Development of an HPLC/MS/MS methodology for determining 3-Omethyldopa in human plasma and its application in a bioequivalence study, Química Nova, 36 (2013) 171-176.

19. K. Igarashi, K. Hotta, F. Kasuya, K. Abe, S. Sakoda, Determination of cabergoline and L-dopa in human plasma using liquid chromatography-tandem mass spectrometry, Journal of Chromatography B, 792 (2003) 55-61.

20. RR. Gonzalez, RF. Fernandez, JL. Vidal, AG. Frenich, J. Perez, Development and validation of an ultra-high performance liquid chromatography-tandem mass-spectrometry (UHPLC$\mathrm{MS} / \mathrm{MS}$ ) method for the simultaneous determination of neurotransmitters in rat brain samples, Journal of Neuroscience Methods, 198 (2011) 187-194.

21. PO. Cinto, ALRS. Souza, AC. Lima, MV. Chaud, MPD. Gremião, LC Evaluation of Intestinal Transport of Praziquantel. Chromatographia, 69 (2009) 213-217.

22. F. Gosetti, E. Mazzucco, M. Gennaro, E. Marengo, Simultaneous determination of sixteen underivatized biogenic amines in human urine by HPLC-MS/MS, Analytical and Bioanalytical Chemistry (ABC), 405 (2013) 907-916.

23. C. Muzzi, E. Bertocci, L. Terzuoli, B. Porcelli, I. Ciari, R. Pagani, R. Guerranti, Simultaneous Determination of Serum Concentrations of Levodopa, Dopamine, 3-O-Methyldopa and $\alpha$-Methyldopa by HPLC, Biomedicine \& Pharmacotherapy, 62 (2008) 253-258.

24. HX. Zhao, H. Mu, YH. Bai, H. Yu, YM. Hu, A rapid method for the determination of dopamine in porcine muscle by precolumn derivatization and HPLC with fluorescence detection, Journal of Pharmaceutical Analysis, 1 (2011) 208-212. 